\title{
Self-interest, wealth and the Book of Proverbs in the South African context: Towards a Smithian alternative
}

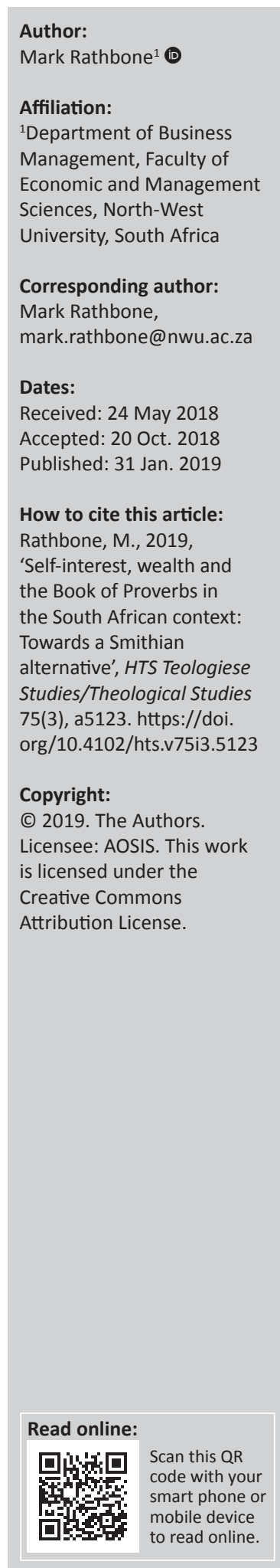

The purpose of this article is to explore new research on Adam Smith (1723-1790), the author of the classic economic text An Inquiry into the Nature and Causes of the Wealth of Nations (1776) and his often-disregarded earlier work The Theory of Moral Sentiments (1759). This is accomplished to provide an alternative perspective on the hermeneutics of wealth in the Book of Proverbs, which is often reduced by Marxist approaches as a mechanism to secure the privilege of the scribal classes of Israel. In order to do this, the following terms generally

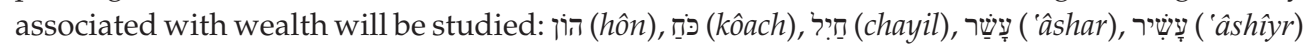
and ('ôsher). This analysis aims to determine whether the assumption of Marxist approaches to biblical interpretation is correct to suggest that wealth is mainly the result of the market dynamics that are exploited by the capitalist classes at the expense of workers. It will be argued that there are similarities between wealth and self-interest as proposed by Smith and the Book of Proverbs. This perspective incorporates self-interest and wealth in a socioethical system in which justice is paramount for social harmony, hereby providing a positive dialogue partner with Marxism and other economic theories to address socio-economic problems in South Africa.

\section{Introduction}

The purpose of this article is to explore new research on Adam Smith (1723-1790), the author of the classic economic text An Inquiry into the Nature and Causes of the Wealth of Nations (WN) (1776) and his often-disregarded earlier work The Theory of Moral Sentiments (TMS) (1759). This is accomplished to provide an alternative perspective on the hermeneutics of wealth in the Book of Proverbs for economics and business (Gonin 2015; Paganelli 2008, 2010; Rathbone 2015; Sen 1999; Wells 2014). This study is a response to interpretations of the Book of Proverbs that follow Marxist approaches and highlight that the sages who compiled the proverbs did so in such a manner as to protect their privileged position in society (Boer 2014; Gottwald 1985; Perdue 2008; Scheffler 2012). The focus on wisdom literature like the Book of Proverbs is important because the instruction of the sages related to the practicalities of daily life and what was deemed as ethical conduct. Although the cosmology of wisdom literature that was underpinned by a retribution system was vastly different from the complexities of contemporary society, it may reveal some similarities to Smithian economics that can contribute to the understanding of the Book of Proverbs today. It will be argued that the perspective on wealth in the Book of Proverbs follows a view of self-interest that is more complex, as suggested by the material analysis of Marxist approaches. This complexity is reflected in the sensitivity shown by Smith to social context and justice - sensitivity also present in the Book of Proverbs. Self-interest is contained in a socio-ethical system influenced by sympathy that limits excess and also highlights justice as the basis for social harmony. These are aspects that have led some scholars to note that there are proto-Marxist tendencies present in Smith's work (Hill 2006). This is important in the South African context because it highlights that no one single approach to address socio-economic issues can adequately reflect the complexity of the context.

The aim of this is not to suggest that Marxist approaches and hermeneutics of suspicion in general are not valuable to biblical scholarship. The encompassing work of Boer, Marxist Criticism of the Hebrew Bible: Second Edition (2014), that focuses on the work of scholars strongly influenced by Marx like Althusser, Gramsci, Deleuze and Guattari has convincingly highlighted the importance of Marxist approaches for biblical scholarship. The focus on Smith is therefore presented as a possible alternative economic perspective and as a foil for Marxism. Although Smith's work preceded Marx and his economics is often criticised as the reason for the greed and exploitation

Note: The collection entitled 'Eben Scheffler Festschrift', sub-edited by Jurie H. le Roux (University of Pretoria) and Christo Lombaard (University of South Africa). 
associated with capitalism, it will be argued that this is a general and stereotypical view of Smith (Stigler 1971). Smith's views are different from Marx because of the difference of approach. Smith, an empiricist influenced by the values of the Enlightenment, attempts to develop an approach that studies the psychological processes involved in morality and economics, while Marx's critical approach, swayed by Hegel, emphasises the revolutionary interventionist view of economics.

The work of Smith is also not without its critics. His contemporary, Jean-Jacques Rousseau (1712-1778), was critical of the Enlightenment optimism and commerce. Rousseau questioned whether the natural instinct of self-interest could advance society and rather opted for a notion of benevolence and sacrifice (Rathbone 2015). The father of macro-economics, John Maynard Keynes, rejected noninterventionist approaches to economics and the idea that supply creates demand for goods and services (Keynes 1926). Deleuze and Guattari (2000) view the private ownership of the means of production advanced by Smith as a form of reterritorialisation and enslavement. From the criticism levelled against Smith, the aim of this article is far humbler and intends to seek possible points of overlaps and dialogue with Marxist approaches from the perspective of Smith that may contribute to the understanding of the Book of Proverbs. This does not mean that the economic philosophy of Smith can be anachronistically traced back to the Book of Proverbs. This would be a failure to acknowledge the sitz im leben of text investigated by source criticism (Von Rad 1972), its unique literary genre (Alter 1992), rhetoric (Hauser 1994) and the wealth of sociocultural and anthropological studies (Overholt 1992), among others.

The reason a Smithian perspective may contribute to the understanding of the Book of Proverbs in the South African context is because of the distinct and diverse history of South Africa that is influenced by the legacy of colonialism, apartheid and globalisation (Rathbone 2016). These influences were aligned with crude forms of capitalism and racism that are possibly linked to current problems like economic inequality, poverty and unemployment, tendencies which Marxism is very successful to uncover (Terreblance 2002, 2012). However, there are also general economic aspects associated with supply and demand that influence the South African economy and need to be considered. Without an inclusive dialogue between Marxism and classic economics, the economic problems of today may be exacerbated. It is therefore suggested that a dialogue between Marxist critique and classic economics, among others, can contribute to a more sustainable future. From this perspective a nuanced understanding of Smith's economics can provide important alternatives for dialogue, specifically for the understanding of the Book of Proverbs.

In this article an overview will be given of Marxist scholarly research in South Africa that highlights that the Book of Proverbs was crafted to secure the self-interest of the scribal classes. Secondly, Smith's view of self-interest, sympathy, wealth and justice as discussed in his earlier work, TMS (1759), will be explored based on new research. Thirdly, an overview of references in the Book of Proverbs to possessions, wealth and riches will be studied. This study will be limited to the following words that are most commonly used to refer

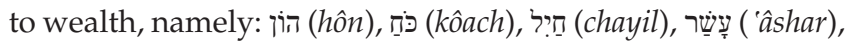

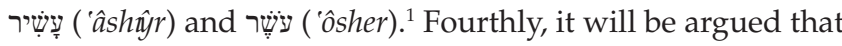
there are similarities between the Smithian approach and the Book of Proverbs in terms of self-interest and wealth that was not solely rooted in protecting the privilege of the sages, as suggested by Marxist approaches to the text.

\section{Marxist approaches and the Book of Proverbs}

In South Africa, poverty, economic inequality and unemployment are unfortunate realities in the daily lives of many people. Marxism is a powerful tool to analyse and provide solutions to address these problems. In biblical scholarship, this approach usually focuses on class distinctions, the role of unequal power relations, the structural problems associated with capitalism and, specifically, the role of self-interest as an immoral foundation for society (Mofokeng 1985). The work of Itumeleng Mosala (1989) on Micah is associated with this approach. Mosala argues that the Bible 'is the site of social, historical, cultural, gender, racial and ideological struggles, and radically and indelibly bear the marks of their origins and history'. The implication, according to Mosala, is that black biblical hermeneutics of liberation 'must battle to recover precisely that history and those origins of struggle in the text and engage them anew in the service of ongoing human struggles' (Mosala 1989:56). This can only be done, according to Mosala, if Black Theology is able to listen to the 'black working-class' and 'poor peasant culture' to discover their authentic experience of injustice as the 'materialist-hermeneutical starting point' of scholarship. Mosala (1989) states that:

The particularity of the black struggle in its different forms and faces must provide the epistemological lens with which the Bible can be read. Only this position seems to represent a theoretical break with dominant biblical hermeneutics; anything else is a tinkering with what in fact must be destroyed. (p. 60)

This materialist approach is a direct Marxist critique of capitalism, the structural dynamics of economic inequality and the class divisions between rich, middle class and poor. It is also a popular approach that is widely used to study the Book of Proverbs.

Scheffler (2012) notes that Bailey regards the Book of Proverbs as a means to continue the privilege of the wealthy:

In ancient Israel's wisdom literature, especially as reflected in the book of Proverbs, the poor mainly are depicted as being responsible for their own poverty ... some positive admonitions to help the poor are not absent, but they are regarded by Bailey as to a great extend [sic] lip service to the plight of the poor, mere

1.Strong's Concordance with Hebrew and Greed Lexicon (2009) was used throughout this article to reference Hebrew and Aramaic words. 
handouts (embalming of the wounds), actually keeping the poor alive in their continuing situation of poverty. (p. 480)

Therefore, any benevolent or humanitarian action is only a means for the wisdom teachers to maintain their socioeconomic position. Scheffler (2012:481) correctly notes that this material analysis of Proverbs is similar to Mosala's Marxist critique of the prophet Micah (Mosala 1989, 1991). Consequently, the elitism, self-interest and inability to function in solidarity with the poor clouded the view of the sages that were responsible for the Proverbs. This perspective has also been supported by Gottwald and Perdue.

Gottwald (1985:573) notes that many remarks on wealth and poverty in the Book of Proverbs are based on neutral observations of sages. However, when they consider the causes of wealth and poverty, various criteria and perspectives come into play. The reason for this, according to Gottwald, is mainly rooted in the social location and self-interest of the sages. The sages enjoyed class privilege because of their vocational status and education - 'their class advantage and tendency to universalize their privileged position prompt them to endorse the operative socioeconomic order as an instance of wise cosmic order' (Gottwald 1985:574). The sages adopted a universal cosmology based on the retribution system that associated wealth with behaviour, which aligned with the social order and piety. On the other hand, poverty resulted from the disruptions of social harmony and was caused by folly. Gottwald argues that this system supported the self-interest of the sages by morally justifying their social position and privilege. However, Gottwald also notes that the sages were not blind to the abuses perpetuated by the wealthy and foolish behaviour that challenged the foundation of the retribution system. So, although the sages attempted to maintain their privilege by adopting the retribution system, the Book of Proverbs also includes observations that are in opposition to this system. Gottwald (1985:575) notes that the dogmatic authoritarian ahistorical wisdom eventually became the dominant perspective because of its practicality and general application that did not deal with observation and exceptions. This perspective followed a retribution system with reward for virtue and punishment for vice (Gottwald 1985:572).

Perdue (2008:100) concurs with this assessment of Gottwald regarding the socio-economic location of the sages. The idealisation of the Book of Proverbs as an undistorted compilation of folk wisdom passed on from generation to generation and later compiled by sages is erroneous. Perdue (2008:103) states that the scholarly consensus is that the Book of Proverbs contains an aristocratic ideology linked to the educated classes, the city, political power, upper classes and wealth:

Farmers, laborers and artisans may have possessed admirable skills along with the wisdom to perform their tasks well, but they were not among the sages who produced the wisdom tradition. (Perdue 1990:476)
Although the proverbs have general appeal and practical benefit, the wisdom tradition was the product of 'welleducated sages whose intelligence and training prepared them for positions in the administration of the major national institutions of government and temple cult' (Perdue 1990:476). Perdue (1990:458) agrees with Gottwald that the paradigm of order triumphed in Israelite wisdom. This paradigm comprises of three integrated spheres, namely cosmology, society and human nature: (1) cosmology highlights the righteous order that functions within a strict retribution system; (2) righteousness relates to the harmonious functioning of society according to the just order; and (3) harmony implies that the righteous person lives in alignment with the cosmic order (Perdue 1990:458).

Scheffler (2012:493) notes that the Marxist approach used by Mosala and Bailey connect the Book of Proverbs to elitist origins. This does not take the diversity of influences that impacted the Proverbs into consideration. Scheffler contends that Bergson's view that self-interest (as opposed to altruism) that dominates human interaction is not the only perspective on wealth in the Book of Proverbs. The opposite is true, according to Scheffler (2012:493), and that is that a more nuanced view of poverty and wealth is present in the text. The book therefore contains a more diverse perspective that is more inclusive of the diverse influences on the final redaction of the text.

Hence, the materialist analysis of Marxist approaches is an attempt to address socio-economic issues like the economic inequality, poverty and unemployment that is so prevalent in South Africa. These socio-economic issues are directly linked to capitalism and market mechanisms that structurally disenfranchise workers and increase inequality (Kahlil 1992). From this perspective, wealth is in many cases related to selfinterest and the assumed injustice of the capitalist system and the positions of privilege of the capitalist class. In this context, the work of scholars like Mosala, Mofokeng and others attempt to uncover the imbedded class structure in the biblical text. This motive is also clear in the work of Gottwald, Perdue, Bailey and others in terms of the Book of Proverbs. The problem of these material analyses is that the biblical text is reduced to a site of class struggle, and the nuanced content is in many cases brushed aside. A further problem of many Marxist approaches is that the link between self-interest, greed and wealth assumes that Smithian economics has no moral compass, social awareness or notion of justice. This makes the notion of wealth contentious and problematic because there is no other perspective than assumed selfinterest possible.

Although many scholars view the Book of Proverbs as a product of an elitist class, there are exceptions. Clements (1976:114) refuted this perception in the seventies. Clements (1976:114) states that although the Israelite wisdom was indebted to educational and intellectual classes associated with the royal court and the wealthy, there are aspects of Proverbs that 'belonged to the simple family life of 
ordinary people'. Further artistic forms of speech in the wisdom tradition like parables, fable allegories and skilful or humorous sayings were popular in the general population, both rural and urban. Therefore, wisdom is not limited to the courts or middle classes and may have had currency long before institutional structure used them as a form of ideological currency. Clements (1976:114) argues that some of the content of the Book of Proverbs is closely associated with the 'old folk heritage of Israel's life'. Although Gottwald and others highlight that the retribution perspective of the scribes became dominant in Israel, it does not alter the fact that diverse influences are contained in the Book of Proverbs. In other words, to equate wealth with the pretence of the sages to secure their privilege is ignoring the fact of the diversity of influences contained in the text.

In the next section the focus shifts to Adam Smith and contemporary research specifically linked to the TMS (1759) that highlights his nuanced view of self-interest, the role of sympathy and the importance of justice for social harmony.

\section{A Smithian alternative}

\section{Self-interest and sympathy}

The economic philosophy of Smith developed in the 18th century is based on a perspective in which self-interest is the framework of commerce (Paganelli 2008; Rathbone 2018). Self-interest, according to Smith, is not a form of morality that is in opposition to benevolence, as suggested by JeanJacques Rousseau (Rathbone 2015:382). It is rather a view of the individual and society that enhances human freedom and innovation. In this context, commerce is the playing field, where products and services are exchanged for the benefit of society and the individual is rewarded by receiving profit. In contemporary economic literature this point of departure of Smith is criticised as the foundation of greed and corruption (Stigler 1971:265). However, recent research on TMS (1759) that bases Smith's moral theory on the notion of sympathy has revealed a far more nuanced view of Smith's economics and his understanding of self-interest. It has become clear that self-interest functions within a socio-ethical context, with justice as a crucial element for sustained social harmony. The role of society and justice in commerce challenges the assumption of some scholars, who singularly view Smith as the foundation of Homo economicus [the money-making man] (Rathbone 2018).

Sympathy, according to Smith, is the basis of moral development and focuses on the ability to judge the behaviour of others and of oneself with the purpose to alter behaviour. Judgement is possible by imagining whether other people who view the subject may approve or disapprove of behaviour (Gonin 2015; Rathbone 2018). Behaviour is then altered to gain societal approbation. The ability to alter behaviour is where moral development takes place. In other words, self-interested behaviour is always contained in a larger socio-ethical context that limits excess and damage to society (Rathbone 2015:383-385). This is a relevant divergence that is important for biblical scholarship that tends to dismiss texts like the Book of Proverbs as elitist and contributing to economic injustice based on Marxist analysis. This is an enlightening perspective that may envision a wider dialogue on economic justice in the South African context. In what follows in this section, Smith's view of wealth will be explored in order to investigate to what extent this perspective may overlap with the Book of Proverbs.

\section{Wealth and justice}

Smith (2004:61) states that sympathy with pleasure explains why the pursuit of wealth is important for people. Poverty is avoided because of the association with pain and suffering. Sympathy with joy has a direct impact on economic activity and the focus on increase of wealth. This is the reason, according to Smith (2004:61), why we work and engage in business. It is part of our nature to be economically active. 'Nay, it is chiefly from this regard to the sentiments of mankind, that we pursue riches and avoid poverty' (Smith 2004:61). Smith (2004:61) argues that work provides the necessities of life like food, clothing and the comfort of a house. This must, however, be distinguished from luxuries. Luxuries have to do with vanity and distinction. This relates to the desire to better your material condition or social position. Vanity has to do with the attempt to better your lifestyle because this will provide approbation and adoration. Wealth draws attention and kindles agreeable emotion from others. Thus, the wealthy person is fond of his or her wealth not for what it can procure but rather for what approbation it ignites. 'The wealthy person is looked upon with sympathy, that joy and exultation with which his circumstances naturally inspire him. His actions are the objects of the public care' (Smith 2004:62). Wealth is observed and taken note of because it has a heightened acceptance.

On the other hand, poverty, according to Smith (2004:62), evokes shame and concealment out of fear of misappropriation and scarcity of sympathy. Poverty is not observed; it is rather avoided. It evokes feelings of sorrow and causes distress. Smith (2004:63-64) highlights that this inclination of people to go along with the passions of the rich and powerful is a matter of nature. We sympathise for their own sake because we are reluctant to give attention to poverty and sorrow.

Material wealth has a significant influence on sympathy. Sympathy is a system of assessment of the behaviour of others and cannot be separated from materiality and ontology. Social interaction takes place in time and space and concerns the assessment of the material well-being of the self and other. Smith was very clear on this matter and the role that material possessions have on the moral development of people. This is not a utilitarian assessment based on rational calculation. It is rather associated with the psychology of moral development. Smith (2004:53) highlights that 'sympathy with sorrow, in a sense, is more universal than with joy'. The reason for this, according to Smith (2004), is because pain:

... of the mind or body, is a more pungent sensation than pleasure, and our sympathy with pain, though it falls greatly short of what 
is naturally felt by the sufferer, is generally a livelier and more distinct perception than our sympathy with pleasure ... (p. 53xx)

This propensity to sympathise with the suffering of others rather than with joy is located in the fact that we are ashamed of our envy of others (Smith 2004:54). Thus, Smith (2004:54) affirms that 'when there is no envy in the case, our propensity to sympathise with joy is much stronger than our propensity to sympathise with sorrow'. The absence of envy leads to a stronger inclination to sympathise with joy rather than sorrow because it is 'painful to go along with grief, and we always enter into it with reluctance' (Smith 2004:56). In other words, suffering is avoided and pleasure embraced. This is the reason why material wealth leads to sympathy. ${ }^{2}$

This material aspect of reality is more encompassingly addressed in WN (1776). In WN the complex dynamics of materiality and scarcity of resources in society is explained in terms of the relationship between supply and demand. Economics is, thus, a specific aspect of social engagement and development of society, and therefore Smith (2004:72) warns against the negative impact of this tendency of human nature to sympathise with wealth and may neglect the poor in society and morality. Although sympathy with wealth and greatness is important for social order, it has the potential to undermine virtue and wisdom. Smith (2004) states:

We frequently see the respectful attention of the world more strongly directed towards the rich and the great, than towards the wise and virtuous. We see frequently the vices and follies of the powerful much less despised than the poverty and weakness of the innocent. (p. 73)

Smith warns that nature can lead to moral decay and we must be aware of its danger to society because it may lead to the devaluation of abilities, merit and virtue (Smith 2004:74). This may be the reason Smith warns against the negative impact of narcissism on society in WN. In contemporary society, this tendency to sympathise with wealth may be an important dimension to understand global economic inequality. It is important to note that Smith does not condone greed and the unjust pursuit of wealth. He simply attempts to understand the psychosocial dynamics that underpin the desire for wealth. In this regard it is crucial to reflect on Smith's conception of justice in order to expose global mechanisms that may be the cause of the disruption of social harmony and lead to inequality.

Justice, according to Smith (2004:93), protects society from economic inequality because of excessive sympathy with wealth that disrupts social harmony (Smith 2004:93). Smith writes that 'the violation of justice is injury: it does real and positive hurt to some particular persons, from motives which are naturally disapproved of' (Smith 2004:93). In other words, injustice requires a positive response of sympathy with the

\footnotetext{
2.It is important to note that Hume objected to Smith's supposed view that all sympathy was agreeable (Smith 2004:56). Smith (2004:56) responded that approbation has two aspects, namely, the sympathetic passion of the spectator and secondy, the emotion that arises from observing the perfect coincidence of sympathetic passion and the passion in the person concerned. The latter is always agreeable, while the former can be both agreeable and disagreeable. Disagreeable approbation is common in a situation of a display of sympathy with injustice.
}

harm experienced by the victim in order to restore harmony to society. This is a crucial aspect of human nature, because although people go along with the idiosyncrasies and folly that wealth may at times display, there is a natural limit when it causes harm. It is at this point that sympathetic resentment demands action or punishment for the transgressor (Smith 2004:91). Sympathetic resentment refers to the role of the spectator who is offended by the clear imbalance between the aroused passions of the perpetrator and suffering of the victim. There is a difference between justice and other virtues. The latter is left to our personal choice to attain approbation. The former is characterised by the fact that we 'feel ourselves to be in a peculiar manner tied, bound, and obliged to the observation of justice' (Smith 2004:93). However, justice is not a positive virtue, because upholding the law and refraining from harming others does not entitle a person to gratitude (Smith 2004:95). 'Mere justice is, upon most occasions, but a negative virtue, and only hinders us from hurting our neighbour' (Smith 2004:95).

Justice is the mechanism that helps guard against excessive self-interest that leads to the exploitation of others. Therefore, there is a natural sympathy with the victims of injustice. Wealth acquired through unjust means is therefore scorned upon and sympathy is with the suffering of the exploited. Smith (2004:96) is confident that justice is nature's way to correct excessive self-interest and narcissism that leads to the harm ${ }^{3}$ of others for self-gain. The reason for this is that there is a natural resistance to the 'incitement to do evil to another' (Smith 2004:96). To harm someone else and disturb his or her happiness for selfish gain will result in the lack of appropriation by the impartial spectator. The impartial spectator has the function to 'humble the arrogance of our self-love' (Smith 2004:97). Smith (2004) notes:

In the race for wealth, and honours, and preferments, he may run as hard as he can, and strain every nerve and every muscle, in order to outstrip all his competitors. But if he should justle, or throw down any of them, the indulgence of the spectators is entirely at an end. It is a violation of fair play, which they cannot admit of. (p. 97)

The spectator will not go along with the self-love of the aggressor that results in the injury of the other. Rather, the sympathy of the spectator will be with the 'natural resentment' of the injured party. The aggressor will become the object of hatred and indignation (Smith 2004:98). In other words, limitless self-love that goes so far as to harm others was never the vision of Smith's view of self-love, as may be perceived in WN.

\section{Possessions, wealth and riches in the Book of Proverbs}

In this section the focus shifts to six terms commonly translated in the Book of Proverbs ${ }^{4}$ with 'possessions', 'wealth' and 'riches': הוֹן (hôn), గị (kôach), חַayil),

3.The various forms of harm that Smith refers to are not all equal. Murder is viewed as the greatest harm, then come loss of property and possessions and lastly personal rights or 'what is due to him from the promises of others' (Smith 2004:98).

4.The New International Version (2011) is used for all Bible references. 


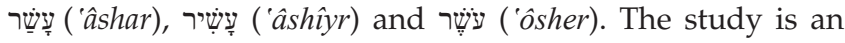
attempt to provide a close reading of the text in which these words are used in order to uncover the finer nuances of the meaning of these words. In other words, the purpose is to determine if the sages solely attempted to maintain privilege by reducing the text to a retribution system in which poverty is viewed as the result of vanity, moral and religious deficiency and, on the other hand, wealth is viewed as the product of constructive effort, wisdom, righteousness and piety. It will be highlighted in this section that in some cases, possessions and wealth are regarded in a more practical way in terms of management and/or warning against vanity. Wealth is also contained in a social and moral system in which justice plays a crucial role that is similar to Smith's view of self-interest.

\section{הוֹ (hôn)}

The word hôn is mainly used as a masculine noun and only twice as an interjection $(30: 15 ; 30: 16)$. The interjection is an admonition of excess. The use of the word as noun is prevalent and refers to wealth, riches or substance or material possession in general. Reference to material possession does not relate to a specific group or class, for example, poor or wealthy. The main focus of these proverbs has to do with the management and use of possessions: to honour the Lord (3:9), charity (6:31), diligent labour (12:27), injustice and the increase of possessions (28:8). The assumption of these references is that there is a religious, moral, just and humanitarian responsibility associated with possessions that does not discriminate between classes.

References to hôn as relates to wealth and riches in most cases are combined with moral admonitions and warnings to exercise self-constraint, act justly and not to give in to vanity - honour and righteousness (8:18), labour and wrath (11:4), humility (13:7), labour versus vanity (13:11), vanity of the wealthy (18:11), knowledge (24:4), justice (28:8), impatience and the increase of wealth (28:22) and moral behaviour (29:3). The overwhelming perspective of these references is related to wealth within society. Wealth must not be gained in ways that are unjust and harm others. Social cohesion and sustainability must be maintained. In 19:4 it is also noted that wealth and poverty have a direct impact on social inclusion and marginalisation. This reference is a warning against social relations that are used for self-promotion, which leads to pride and excessive self-interest.

In 10:15 the only outright positive reference is made to wealth. However, it is connected to security and harmony 'The rich man's wealth is his strong city; the destruction of the poor is their poverty'. This reference should be read in conjunction with 18:11 - 'The rich man's wealth is his strong city, and as a high wall his own conceit'. In this context the security of wealth is viewed in the context of conceit. Hence wealth can be a source of security and it may also be the basis for false security. The reason for this is because 18:10 highlights that only the name of the Lord is a strong tower where the righteous find refuge. In other words, the righteous do not find security in false securities and false friends (19:4).
Wealth is a responsibility that implies that a person needs to ethically consider his or her behaviour. A person should also not be misled into believing that wealth is a form of security, because God is the only security of the righteous and wise.

\section{ñذ่ (kôach)}

The word kôach is a masculine noun that has two categories of meaning: strength, power, might or wealth, and it can also refer to a reptile or lizard that is unclean. In 5:10 the reference is used in the context of wisdom teaching and responsible conduct. Effort is required to protect possessions against the malicious conduct of others. It is clear from the use of kôach that it is generally used to refer to material possession gained through labour and does not refer to class distinction. It may be possible that kôach can be associated with the folk heritage of Israel referred to by Clements. The reason for this is that general regard for possessions is probably something that parents taught their children. This reflects the family context of the folk wisdom.

\section{חַי (chayil)}

Chayil is a masculine noun that refers to strength, might, efficiency, ability and wealth. In 13:22 it is stated that the good or wise person leaves an inheritance for his descendent and that the wealth of the sinner goes to the just. The implication is that wealth in a harmonious system may be in the hands of sinners; however, its ultimate destination is the righteous. This is a clear support of a retribution system that may support the privilege of the intellectual class. The context of this relationship between wealth and justice is in terms of an inheritance and the way in which material possessions are managed. The point is that although there may be failures to keep possessions secure, the fact is that ultimately order will prevail. As was the case with kôach, it is possible that chayil can be associated with family and folk wisdom.

\section{עִ ('âshar)}

The word 'âshar is used as a verb referring to wealth creation or becoming rich. There are many positive appraisals of wealth creation that are associated with diligence (10:4); wealth is created by God and is a blessing (10:22); wealth and morality - wealth does not come from a focus on pleasure and wine (21:17). The more negative view of wealth is that it may lead to pretence, for example, pretending to be rich versus the truly wealthy who do not need to make a show of their wealth (13:17); wealth is not a goal in itself (23:4); and hasty pursuit of wealth may lead to unjust practices $(28: 20)$.

The word 'âshar does give the impression that the retribution system is supported because hard work, piety and morality are linked to wealth creation. The implication, according to the text, is that a wealthy person is also a moral person; a connotation that would not specifically enhance the 
privilege of the scribal class. It is rather an attempt to highlight that virtue and prudence in business are crucial for success. The warning that wealth creation may also lead to a loss of direction in life and injustice indicates impediments to wisdom. The wise would refrain from developing an elevated view of the self, focusing on wealth as the purpose of life. The vanity of wealth is a clear problem for the sages.

\section{עִּנִשיר ('âshîyr)}

The word 'âshîyr is used as a noun and translated as 'riches' or 'wealth'. It is also used as an adjective, for example, 'rich' and 'wealthy'. The occurrences of 'âshîyr as an adjective ['the rich man'] are generally made as a comparison between rich and poor $(14: 20 ; 18: 23)$. Most of the Proverbs are critical of 'the rich man', except for 10:15. The critique relates to social relations (14:20); conceit and self-reliance (18:11); attitude (18:23). The statement about social relations in 14:20 can be taken as positive and/or negative in terms of the false social priority of the wealthy because of elevated self-perceptions and the marginalisation of the poor.

The word 'âshîyr used as a noun is mostly a negative evaluation of 'the rich' in terms of conceit (28:11); abusive power of the rich and oppression of the poor $(22: 7 ; 22: 16)$; righteousness of the poor and perversion of the rich (28:6). The only use that can be construed as positive is in Proverbs 22:2, which states that the rich and poor are created by God. This may also simply be viewed as an emphasis on the cosmology of the scribes, in which a person's class is part of the order of society. The implication is that it seems to be impossible or against God's providence to move between classes. This verse clearly supports the retribution system with a focus on the preservation of the privilege of the scribal class. However, the largest majority of the verses are extremely critical of the 'âshîyr. Although âshîyr can be linked to the retribution system, it is evident that excess and vanity are frowned upon.

\section{עִֶׁׁ ('ôsher)}

The noun 'ôsher is translated as riches and is generally used with reference to the connection between riches and wisdom. The causality of the retribution system is clear in 3:16 and $8: 18$, in which the teaching of the sages is on the topics of honour, righteousness and riches. Riches are also positively associated with strength (11:16); security of life (13:8); crown (14:24); riches, piety, humility, honour and life placed in relation to one another (22:4). These occurrences support the thesis that scribes may have used the Book of Proverbs to secure their privilege because wealth is associated with moral conduct. However, there are a couple of verses that portray a negative view of riches because a person's security cannot be based on riches. Security is rooted in a life of righteousness (11:28); honour (e.g. good name, 22:1); having enough for life and sustainability (30:8). As was the case with 'âshîyr, self-interest is placed in the wider societal context and justice.

\section{Wealth, Smith and the Book of Proverbs}

The preceding discussion of words associated with wealth in the Book of Proverbs highlights interesting connections between Smith's view of material possessions and that of the scribes. For Smith, wealth is always linked to responsibility and careful management of possessions in a just manner that must not be corrupted by vanity. A similar view is found in the Book of Proverbs, which highlights the responsible management of possessions and/or wealth and the importance of justice as a means to limit the negative impact of excess and narcissism (e.g. 'âshîyr, 'ôsher).

The argument of scholars like Gottwald (1985), Perdue (2008) and Bailey (2010), who view the Book of Proverbs as a mechanism of the elitist classes of scribes to sustain their privilege based on the retribution system, is clearly present in references to wealth. However, this is not the most prevalent reference and is only found in the following cases: aw-shar; 'âshîyr, hôn [used as 'wealth']; and 'ôsher. The majority of other references in the case of kôach, hôn [used as 'possessions'] and $k h a k^{\prime}$-yil are not limited to wealth or wealthy in terms of a class in society. These references refer to effort, possessions and ability without clear reference to a wealthy class as opposed to poor or working classes. In the Book of Proverbs, the management of possessions as being wise, virtuous, pious and righteous conduct is found in the case of kôach (5:10) and hôn $(3: 9 ; 6: 31 ; 12: 27)$. Direct reference to wealth in the case of hôn is similar to that of Smith, who highlights the responsible management of wealth. It is further important to note that these references can be associated with family and folk wisdom, as noted by Clements.

La Sor (1982:547) state that Hebrew wisdom is the 'art of success', of which the Book of Proverbs is a 'guidebook for successful living' that refers to negative and positive rules for life. The text serves as a clarification on 'right and wrong conduct in a host of situations' in order to achieve success, wealth and social harmony (1982:548). The assumption of La Sor (1982) is that appropriate conduct is situational and that, as is found in Smith, it implies a social context. Smith goes to great lengths to explain why people have a natural sympathy towards wealth and success as opposed to poverty. Poverty, in the case of Smith and the Book of Proverbs, is linked with suffering and the lack of resources, which must be avoided. Therefore, references to 'âshîyr and âshar highlight that the wise person should take care of his possessions to avoid poverty. From the perspective of the retribution system, poverty can be related to folly, as is the case with ôsher and khah'-yil. However, injustice and vanity are rejected in all references to wealth as morally and spiritually unacceptable. This is similar to Smith, who identifies vanity and gains through injustice as a danger for social cohesion and harmony. Wealth is not rejected, as is the case with Marxism; however, the means of accumulation of wealth is qualified. This perspective on wealth in Proverbs aligns with the study of Biwul (2017) on the use of the word hebel in Ecclesiastes. 
Biwul (2017) notes that hebel is a literary rhetorical device that is used to critique the practices of the wealthy and powerful and not merely a device to secure the privilege of the sages.

This study of wealth in the Book of Proverbs and similarities with Smith's view of self-interest highlight that a materialist analysis alone does not provide a comprehensive understanding of the Book of Proverbs. At most it highlights that there may be certain inscribed ideological traces, associated with the retribution system, that need to be considered. What has become clear is that the text is also concerned with material possession in general, responsibility in dealing with possessions and warnings against vanity. These references exclude wealth in terms of excess; it rather refers to the joy and responsibility of owning something that makes life easier. This responsibility is indeed linked to wisdom and the religious views of people. It can therefore be inferred that self-interest and possession are not negative virtues; rather self-interest needs to be understood in the wider context of society and justice. This more nuanced perspective on self-interest is important for scholarship in South Africa because it emphasises that economics are complex and that diverse perspectives are required to address socio-economic issues like poverty, unemployment and inequality. The fact of the matter is that to address poverty in South Africa, society needs to deal with the greed of corruption and state capture as much as it has to deal with the narcissism of capitalism.

Practically, the understanding of the Book of Proverbs from a Smithian perspective provides biblical values that are crucial for business. Aspects like justice, philanthropy, responsible and prudent business practices are all emphasised and could contribute to disciplines like business ethics. On the other hand, a Smithian approach is also an important dialogue partner with economic theories like Marxism and the understanding of the Bible. The contribution of a Smithian approach is its sophisticated socio-ethical analysis, which may enhance business as an embedded social phenomenon that can contribute to sustainable and stable societies in the local and global context.

\section{Conclusion}

In this article, wealth in the Book of Proverbs was studied in order to ascertain whether the conclusion of Marxist approaches to biblical scholarship is correct in arguing that the scribes responsible for the Book of Proverbs exclusively promoted their self-interest and privilege. An investigation into the work of Adam Smith revealed that self-interest is never reduced to egoism and uncontained excess. Selfinterest is only the framework for commerce, and it is contained in a socio-ethical system in which sympathy is the basis for human interaction and moral development. From this perspective wealth, according to Smith, does gain the sympathy of people. As is the case with the Book of Proverbs, wealth has a positive association following the logic of the retribution system. However, for Smith and the scribes, wealth and self-interest are contained. For the scribes, wealth that leads to vanity and/or wealth gained though unjust means is rejected. Smith has a similar view that highlights that justice is crucial for the harmonious functioning of society. The implication of these findings is that wealth in the Book of Proverbs does contain clear divergences from the perspective of Marxist approaches. The functioning of the retribution system allowed for anomalies because of unjust behaviour in securing wealth and this is similar to Smith's view on self-interest, which was far more nuanced than previously claimed.

The Smithian approach to the Book of Proverbs may provide a biblical perspective for business and economics in South Africa for disciplines like business ethics. It can also positively contribute to dialogue with Marxism and other economic perspectives by providing a sophisticated economic analysis that is socio-ethically embedded. These aspects, among others, can creatively afford perspectives to address issues like economic inequality, poverty and unemployment in South Africa.

\section{Acknowledgements Competing interests}

The author declares that he has no financial or personal relationships that may have inappropriately influenced him in writing this article.

\section{References}

Alter, R., 1992, The world of biblical literature, Basic Books, New York.

Bailey, R 2010, Communication during the discussion of the module 'The Bible and the eradication of poverty', (cf. Scheffler \& Van Heerden [eds.] 2012) being taught at the University of South Africa, UNISA, Pretoria.

Biwul, J.K.T., 2017, 'The use of hebel in Ecclesiastes: A political and economic reading', HTS Teologiese Studies/Theological Studies 73(3), 1-10. https://doi.org/10.4102/ hts.v73i3.4571

Boer, R., 2014, Marxist criticism of the Hebrew Bible: Second edition, Bloomsbury, London.

Clements, R.E., 1976, 'The social world of the wisdom writers', in R.E. Clements (ed.), The world of ancient Israel, pp. 227-250, Cambridge University, Cambridge.

Deleuze, G. \& Guattari, F., [1972] 2000, Anti-oedipus: Capitalism and schizophrenia, University of Minnesota Press, Minneapolis, MN.

Gonin, M., 2015, 'Adam Smith's contribution to business ethics, then and now', Journal of Business Ethics 129, 221-236. https://doi.org/10.1007/s10551-014-2153-4

Gottwald, N.K., 1985, The Hebrew Bible: A socio-literary introduction, Fortress Press, Philadelphia, PA.

Hauser, A.L., 1994, 'Rhetorical criticism of the old testament', Rhetorical criticism of the Bible, Brill, Leiden.

Hill, L., 2006, 'Adam Smith and the theme of corruption', The Review of Politics 68 , 636-662. https://doi.org/10.1017/S0034670506000210

Kahlil, E.L., 1992, 'Marx's understanding of the essence of capitalism', History of Economics Review 17, 19-32.

Keynes, J.M., 1926, The end of laissez-faire, The Hogarth Press, London.

La Sor, W.S., 1982, Old Testament survey: The message, form, and background of the Old Testament, William B. Eerdmans Publishing Company, Grand Rapids, MI.

Mofokeng, T.A., 1985, 'Reconciliation and freedom', in J.W. De Gruchy (ed.), Cry freedom: Prayers, meditations and readings from South Africa, Collins, Cape Town.

Mosala, I.J., 1989, Biblical hermeneutics and black theology in South Africa, Eerdmans, Grand Rapids, Ml.

Mosala, I.J., 1991, 'Ownership or (non)ownership of the land forms the basis of wealth and poverty: A black theological perspective', in H.L. Bosman, I.G.P. Gous \& I.J.J. Spangenberg (eds.), Plutocrats and paupers: Wealth and poverty in the Old Testament, pp. 20-24, J.L. Van Schaik, Pretoria.

Overholt, T.W., 1992, Cultural anthropology and the old testament, Fortress Press, Minneapolis, MN.

Paganelli, M.P., 2008, 'The Adam Smith problem in reverse: Self-interest in the wealth of nations and the theory of moral sentiments, History of Political Economy 40(2), 365-382.https://doi.org/10.1215/00182702-2008-006 
Paganelli, M.P., 2010, 'The moralizing distance in Adam Smith: The theory of mora sentiments as possible praise of commerce', History of Political Economy 42(3), 425-441. https://doi.org/10.1215/00182702-2010-019

Perdue, L.G., 1990, 'Cosmology and the social order in the wisdom tradition', in L.G. Perdue \& J.G. Gammie (eds.), The sages in Israel and the ancient near east, pp. 457-478, Eisenbrauns, Winona Lake, IN.

Perdue, L.G., 2008, The sword and the stylus: An introduction to wisdom in the age of empires, William B. Eerdmans, Grand Rapids, MI.

Rathbone, M., 2015, 'Love, money and madness: Money in the economic philosophies of Adam Smith and Jean-Jacques Rousseau', Southern African Journal of Philosophy 34(3), 379-389. https://doi.org/10.1080/02580136.2015. 1087614

Rathbone, M., 2016, 'Reframing the tower of Babel narrative for economic justice within the South African context', HTS Theological Studies 72(3), 1-9.https://doi. org/10.4102/hts.v72i3.3490

Rathbone, M., 2018, 'Adam Smith, the impartial spectator and embodiment: Towards an economics of accountability and dialogue', Religions 9, 118. https://doi.org/ $10.3390 /$ rel9040118
Scheffler, E., 2012, 'Poverty in the Book of Proverbs: Looking from above?', Scriptura 111(2012:3), 480-496.

Sen, A., 1999, On ethics and economics, Blackwell, London.

Smith, A., [1759] 2004, The theory of moral sentiments, Cambridge University Press, Cambridge.

Smith, A., [1776] 1950, 'An inquiry into the nature and causes of the wealth of nations', in E. Cannan (ed.), Edited with introduction, notes, marginal summary and an enlarged index, Methuen \& Co. Ltd., London.

Stigler, G.J., 1971, 'Smith's travel on the ship of state', History of Political Economy 3(2), 265-277. https://doi.org/10.1215/00182702-3-2-265

Terreblance, S., 2002, A history of inequality, 1652-2002, University of Natal Press, Pietermaritzburg.

Terreblance, S., 2012, Lost in transformation: South Africa's search for a new future since 1986, KMM Review Publishing Company, Johannesburg.

Von Rad, G., 1972, Wisdom in Israel, Abingdon, New York.

Wells, T.R., 2014, 'Recovering Adam Smith's ethical economics', Real-World Economics Review 68, 90-97. 